\title{
Carbamylphosphate Synthetase Deficiency in an Infant with Severe Cerebral Damage
}

\author{
F. A. HOMMES, C. J. DE GROOT, C. W. WILMINK, and J. H. P. JONXIS \\ From the Department of Paediatrics, University of Groningen, School of Medicine, Groningen, The Netherlands
}

The biosynthesis of urea from ammonia and carbon dioxide requires five enzymes. One enzyme, carbamylphosphate synthetase converts ammonia and bicarbonate to carbamyl phosphate, which subsequently condenses with ornithine to form citrulline, a reaction catalysed by ornithine transcarbamylase. Citrulline is then converted by argininosuccinic acid synthetase to argininosuccinic acid, which is cleaved to form arginine and fumaric acid. The enzyme arginase finally converts arginine to ornithine and urea.

All of these enzymes, with the exception of arginase, have been associated with an inborn error of metabolism: hyperammonaemia with a defective ornithine transcarbamylase (Russell et al., 1962; Levin and Russell, 1967), citrullinaemia with a defective argininosuccinate synthetase (McMurray et al., 1962), and argininosuccinic aciduria with a defective argininosuccinic acid cleavage enzyme (Allen et al., 1958).

Mental retardation is a common feature of these enzymatic defects, but it is uncertain whether the cerebral defect is due to accumulation of ammonia. There is increasing evidence that the urea cycle proceeds in the brain cells (Sporn et al., 1959; Kemp and Woodbury, 1965), so that brain damage may be due to toxic effects of accumulated urea cycle intermediates and not necessarily to a high ammonia level.

Five cases with a high blood ammonia level (postprandial ammonaemia) due to enzymatic defects have been described. In 4 of these cases enzyme activity determinations have been carried out (Freeman et al., 1964; Russell et al., 1962; Levin and Russell, 1967). In the case described by Freeman et al. (1964) a reduced activity of carbamylphosphate synthetase with normal activities of the other enzymes of the urea cycle was found. The other 3 cases showed a very low activity of liver ornithine transcarbamylase, though the activity of carbamylphosphate synthetase was also below the normal value (see Addendum).

Received April 21, 1969.
A case is described of carbamylphosphate synthetase deficiency with normal ornithine transcarbamylase activity.

\section{Case Report}

This child, born July 18, 1967, was admitted to hospital at the age of 20 days, because she fed poorly, was lethargic, and had irregular eye movements and slight convulsions. She had been born after an uncomplicated pregnancy of 40 weeks. Birthweight $3250 \mathrm{~g}$.

Two other children of this family had died with similar symptoms, both at the age of 4 weeks, a boy born in 1962 and a girl born in 1965. Necropsies of these sibs showed extensive cerebral spongy degeneration, especially of the brain-stem and basal nuclei. 2 other children of the same marriage are normal.

On admission the infant's weight was $3490 \mathrm{~g}$. She was extremely lethargic. Tendon reflexes were decreased. Moro reflex was absent. Bilateral papilloedema was present. Liver and spleen were not enlarged. EEG on admission showed no epileptic activity or other gross abnormalities of the wave pattern. At the age of 2 months, however, epileptic activity was noted in the EEG, and at an age of 7 months generalized paroxysmal high voltage complexes were present with maximum voltage occipital $(200-400 \mu \mathrm{V})$ at a frequency of 2-4 per 10 sec.

Hb 19.4 g. $/ 100 \mathrm{ml}$.; haematocrit $60 \%$; erythrocytes $4.08 \times 10^{6} /$ cu.mm.; leucocytes $6600 /$ cu.mm.; thrombocytes 247,000/cu.mm.; reticulocytes $2 \%$. Serum electrolytes were within normal limits. Lactic dehydrogenase $400 \mathrm{U}$ per ml.; SGOT and SGPT normal. Serum protein $4.8 \mathrm{~g} . / 100 \mathrm{ml}$; $46 \cdot 7 \%$ albumin, $6 \cdot 6 \%$ $a_{1}$-globulin, 9.8\% $a_{2}$-globulin, 9.9\% $\beta_{1}$-globulin, $5 \cdot 2 \% \beta_{2}$-globulin, and $21 \cdot 8 \% \gamma$-globulin. CSF: no cells, protein content normal, with a normal differentiation. Fasting blood glucose levels varied between 100 and $150 \mathrm{mg} . / 100 \mathrm{ml}$.

A summary of medication and diet is given in Table I, along with blood $p \mathrm{H}$ values, and urea and ammonia concentrations in plasma. A slight metabolic alkalosis was present. Blood urea values were low at all times, even taking into account the relatively low protein intake. The infant did not gain weight, nor was she in positive nitrogen balance, a situation that normally leads to an increased blood urea concentration. The blood ammonia levels were in the upper range of normal 
TABLE I

Biochemical Data, Diet, and Treatment of Patient

\begin{tabular}{|c|c|c|c|c|c|c|}
\hline $\begin{array}{c}\text { Age } \\
\text { (days) }\end{array}$ & Blood $p H$ & $\begin{array}{c}\text { Blood } \\
\text { Standard } \\
\text { Bicarbonate } \\
(\mathrm{mEq} / \mathrm{l} .)\end{array}$ & $\begin{array}{l}\text { Blood Urea } \\
(\mathrm{mg} . / 100 \mathrm{ml} .)\end{array}$ & $\begin{array}{c}\text { Blood } \\
\text { Ammonia } \\
(\mu \mathrm{g} . / 100 \mathrm{ml} .)\end{array}$ & $\begin{array}{l}\text { Protein } \\
\text { Intake } \\
\text { (g./kg.) }\end{array}$ & Therapy \\
\hline $\begin{array}{r}20 \\
24 \\
28 \\
30 \\
49 \\
64 \\
74 \\
79 \\
84 \\
92 \\
126 \\
130 \\
149 \\
151 \\
160 \\
176 \\
183 \\
190 \\
206 \\
213 \\
231 \\
233\end{array}$ & $\begin{array}{l}7 \cdot 42 \\
7 \cdot 44\end{array}$ & $\begin{array}{l}23 \\
28\end{array}$ & $\begin{array}{r}35 \\
21 \\
\\
7 \\
\\
6 \\
13 \\
5 \\
4 \\
\\
1 \\
2 \\
2 \\
11 \\
9 \\
8 \\
12 \\
11 \\
14\end{array}$ & $\begin{array}{r}100 \\
55 \\
25 \\
30 \\
43 \\
75 \\
35\end{array}$ & $\begin{array}{l}2.5 \\
2.5 \\
0 \\
0.5 \\
0.5 \\
1.0 \\
1 \cdot 0 \\
2.0 \\
1.0 \\
1.5 \\
1.5 \\
1.5 \\
1.5 \\
1.5 \\
1.5\end{array}$ & $\begin{array}{l}3 \times 20 \text { mg. phenobarbitone } \\
\text { Phenobarbitone treatment stopped; } 3 \times 5 \mathrm{mg} \text {. } \\
\text { diphantoin } \\
\text { Diphantoin treatment stopped } 2 \times 0.1 \mathrm{U} \\
\text { insulin i.v. } \\
\text { Insulin treatment stopped } \\
\text { Blood transfusion, } 40 \mathrm{ml} . \\
2 \text { mg. ethyloestrenol } \\
\text { Ethyloestrenol treatment stopped } \\
\text { Glucose } 5 \%, 500 \text { ml. } / 24 \text { hr. }\end{array}$ \\
\hline
\end{tabular}

(normal range: $20-60 \gamma / 100 \mathrm{ml}$.). This suggested a defect in the urea cycle, later confirmed by assay of the appropriate liver enzymes in liver tissue obtained by biopsy.

Shortly after admission a formula low in protein was prescribed, and at first there was an improvement in the general condition, but later she began to deteriorate, and she died aged $7 \frac{1}{2}$ months.

At necropsy no gross abnormalities were found. Microscopical examination of the brain revealed spongy degeneration, especially in the brain-stem and basal nuclei, bilateral and symmetrical. These microscopical appearances were similar to those observed in the sibs who had died after a similar clinical course.

\section{Methods}

Amino acids were analysed by the photoelectric ninhydrin method of Moore and Stein (1954) with an automatic Spinco Beckman Amino Acid Analyzer. Plasma and CSF were deproteinized with picric acid (Stein and Moore, 1954). Blood lactate and pyruvate were estimated enzymatically as described by Hohorst (1965), and ammonia as described by Gips (1968). Oxygen consumption was measured by the open method of Noyons, using a diaferometer (Kipp, Delft, The Netherlands). A test for maple syrup urine disease with leucocytes was carried out (Dancis, Hutzler, and Levitz, 1963). The enzymes of the urea cycle were determined by the methods of Brown and Cohen (1959), with minor modifications. Activities of enzymes of glycolysis of liver and brain were determined fluorimetrically using an Eppendorf fluorimeter as described by Estabrook and Maitra (1962), by coupling to a nicotinamide adenine dinucleotide-dependent system in such a way that the enzyme to be tested was made rate-limiting (Bergmeyer, 1968). An aliquot of the homogenate was diluted to $3 \mathrm{ml}$. in a buffer containing $80 \mathrm{mM}$. triethanolamine, $20 \mathrm{mM} \mathrm{KC1}, 10 \mathrm{mM} \mathrm{NaCl}$,

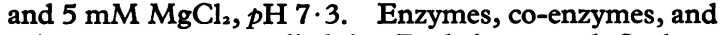
substrates were supplied by Boehringer and Soehne, Mannhein, Germany, and used without further purification. Liver biopsy material (about $10 \mathrm{mg}$.), obtained with a Menghini needle, was homogenized in ice-cold $0.25 \mathrm{M}$ sucrose and $10 \mathrm{mM}$ triethanolamine, pH 7.4. For the assay of urea cycle enzymes whole homogenates were used; for glycolytic enzymes the homogenates were centrifuged for 1 hour at $0{ }^{\circ} \mathrm{C}$. at 20,000 r.p.m. and the supernatant used. Post-mortem tissue was homogenized in the ice-cold 0.44 sucrose and $10 \mathrm{mM}$ triethanolamine, $\mathrm{pH} 7 \cdot 4$.

\section{Results}

As the post-mortem examination of the brain of the patient's sibs had been thought to show some features of maple syrup urine disease, the patient's leucocytes were incubated with $1-{ }^{14} \mathrm{C}$-leucine to determine the rate of oxidative decarboxylation of the corresponding ketoacid, though the plasma amino acid levels (see below) were not indicative of this disease. After incubation for 1 hour at $37^{\circ} \mathrm{C}$. of leucocyte-enriched blood, a healthy control gave a production of $0.91 \mathrm{~m} \mu$ moles of $\mathrm{CO}_{2}$, a value well in line with those published by Dancis, Hutzler, and Levitz (1960). The same 
TABLE II

Amino Acids in Plasma and CSF ( $\mu$ moles $/ \mathrm{ml}$.)

\begin{tabular}{|c|c|c|c|}
\hline & \multicolumn{2}{|c|}{ Plasma } & \multirow{2}{*}{$\frac{\text { CSF }}{\text { Age } 224 \text { days }}$} \\
\hline & Age 20 days & Age 213 days & \\
\hline 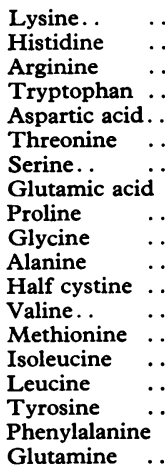 & $\begin{array}{l}0 \cdot 22 \\
0.06 \\
0 \cdot 04 \\
0 \cdot 01 \\
0 \cdot 01 \\
0 \cdot 11 \\
0 \cdot 51 \\
0 \cdot 11 \\
0 \cdot 23 \\
0 \cdot 14 \\
0 \cdot 31 \\
0 \cdot 04 \\
0 \cdot 25 \\
0.02 \\
0 \cdot 10 \\
0.15 \\
0.07 \\
0.04 \\
-\end{array}$ & $\begin{array}{l}0.27 \\
0.07 \\
0.06 \\
0.02\end{array}$ & $\begin{array}{l}0.08 \\
0.03 \\
0.007 \\
- \\
0.002 \\
0.05 \\
- \\
0.008 \\
0.02 \\
0.01 \\
0.04 \\
0.009 \\
0.03 \\
-. \\
0.008 \\
0.02 \\
0.01 \\
0.009 \\
0.59\end{array}$ \\
\hline
\end{tabular}

procedure with the patient's leucocyte-enriched blood gave $0.60 \mathrm{~m} \mu$ moles of $\mathrm{CO}_{2}$. Since in maple syrup urine disease there is complete absence of $\mathrm{CO}_{2}$ production (Dancis et al., 1960 and 1963), maple syrup urine disease should be excluded.

The plasma amino acid analysis (Table II) gave a normal pattern except for arginine which was significantly reduced. Our laboratory normal value for arginine for children of that age is 0.10 $\mu$ moles $/ \mathrm{ml}$., with a standard deviation of 0.02 .

A similarly low arginine level was observed in CSF, $0.007 \mu \mathrm{moles} / \mathrm{ml}$. as compared to a normal value of $0.02 \mu \mathrm{moles} / \mathrm{ml}$. Other amino acids in CSF, including glutamine, were within normal limits. This was to be expected, as blood ammonia levels were only in the upper range of normal.

The high initial blood glucose levels, combined with low blood pyruvate and lactate concentrations $(1.3$ and $3.0 \mathrm{mg} . / 100 \mathrm{ml}$., respectively) and a moderately low over-all oxygen consumption $(5 \mathrm{ml} . / \mathrm{kg}$. per min.) suggested a low capacity for glycolysis. Liver tissue, obtained by biopsy, gave a low activity of hexokinase and glucokinase (Table III, column 1) and an abnormal ratio of the two enzymes (with a normal diet the expected ratio is 4, Walker, Khan, and Eaton, 1966). The glucokinase activity was low, having regard to the carbohydrate-rich diet of the patient at this time (c.f. Walker et al. 1966). A second line of evidence for a disturbed carbohydrate metabolism came from the leucine tolerance curve (Fig.). Only a moderate

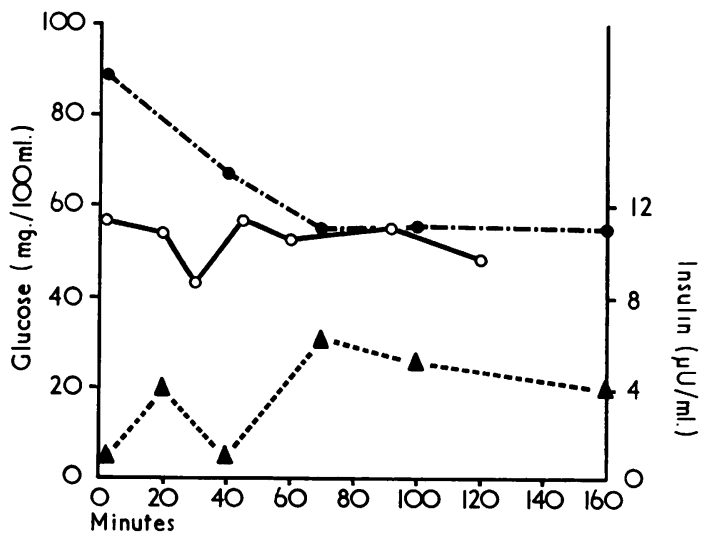

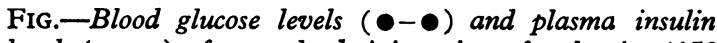
levels $(\mathbf{\Delta}-\mathbf{\Delta})$ after oral administration of L-leucine $(150$ mg./kg.). Blood glucose levels $(0-0)$ after oral administration of L-arginine $(100 \mathrm{mg} . / \mathrm{kg}$.) are also shown.

TABLE III

Activities of Glycolytic Enzymes and of Some Enzymes Associated with Glycolysis in Liver and Brain (in umoles/min. per g. wet weight of tissue)

\begin{tabular}{|c|c|c|c|c|c|c|c|c|c|c|c|c|c|c|}
\hline & & & & & & & & & & & \multicolumn{3}{|c|}{ Liver } & \multirow{2}{*}{$\frac{\text { Brain }}{\text { Post mortem }}$} \\
\hline & & & & & & & & & & & Age 31 days & Age 56 days & Post mortem & \\
\hline \multirow{2}{*}{$\begin{array}{l}\text { Hexokinase } \\
\text { Glucokinase }\end{array}$} & . & . & $\cdots$ & . & $\cdots$ & . & $\cdots$ & $\cdots$ & . & $\cdots$ & \multirow{4}{*}{$\begin{array}{l}0 \cdot 18 \\
0 \cdot 23 \\
0 \cdot 52 \\
1 \cdot 95\end{array}$} & \multirow{4}{*}{$\begin{array}{l}0 \cdot 37 \\
1 \cdot 45 \\
0 \cdot 27 \\
0 \cdot 44\end{array}$} & \multirow{5}{*}{$\begin{array}{l}0.42 \\
1 \cdot 40 \\
1 \cdot 33 \\
5 \cdot 32 \\
218\end{array}$} & $0 \cdot 10$ \\
\hline & . & . & . & . & . & . & . & . & . & . & & & & 一 \\
\hline G6PD .. & .. & $\ldots$ & . & . & $\ldots$ & . & . & .. & . & . & & & & $0 \cdot 28$ \\
\hline \multicolumn{5}{|c|}{ 6-Phosphogluconate dehydrogenase. . } & . & . & .. & . & .. & $\ldots$ & & & & 0.43 \\
\hline \multicolumn{3}{|c|}{ Phosphoglucoisomerase } & . & . & . & .. & . & . & . & $\ldots$ & - & - & & $26 \cdot 3$ \\
\hline \multicolumn{3}{|c|}{ Phosphoglucomutase . . } & . & . & . & $\cdots$ & . & . & . & . & $2 \cdot 71$ & $1 \cdot 34$ & $4 \cdot 13$ & $0 \cdot 23$ \\
\hline \multicolumn{3}{|c|}{ Phosphofructokinase . . } & . & . & . & . & . & . & . & . & $0 \cdot 78$ & 0.67 & $1 \cdot 33$ & $0 \cdot 14$ \\
\hline \multirow{3}{*}{\multicolumn{5}{|c|}{$\begin{array}{l}\text { Aldolase } \quad \ldots \\
\alpha \text {-Glycerophosphate dehydrogenase } \\
\text { Glyceraldehyde phosphate dehydrogenase }\end{array}$}} & . & . & . & . & . & . & $2 \cdot 03$ & $1 \cdot 09$ & $6 \cdot 23$ & 0.84 \\
\hline & & & & & . & $\ldots$ & . & . & .. & $\ldots$ & $2 \cdot 66$ & $3 \cdot 11$ & $8 \cdot 33$ & $0 \cdot 40$ \\
\hline & & & & & $\ldots$ & . & . & .. & .. & $\ldots$ & $17 \cdot 0$ & $18 \cdot 0$ & $30 \cdot 2$ & $3 \cdot 89$ \\
\hline \multicolumn{3}{|c|}{ Phosphoglycerate kinase } & . & . & . & $\ldots$ & . & $\ldots$ & . & $\ldots$ & $15 \cdot 2$ & $33 \cdot 1$ & $36 \cdot 1$ & $4 \cdot 75$ \\
\hline \multicolumn{3}{|c|}{ Phosphoglycerate mutase } & $\ldots$ & $\ldots$ & . & $\ldots$ & $\ldots$ & . & . & . & $20 \cdot 0$ & $38 \cdot 1$ & $33 \cdot 6$ & $8 \cdot 86$ \\
\hline \multirow{3}{*}{\multicolumn{3}{|c|}{$\begin{array}{l}\text { Enolase } \quad \ldots \\
\text { Pyruvate kinase } \\
\text { Lactate dehydrogenase }\end{array}$}} & $\ldots$ & $\ldots$ & . & $\ldots$ & . & . & . & . & $17 \cdot 7$ & $55 \cdot 9$ & $15 \cdot 7$ & 0.55 \\
\hline & & & . & . & . & .. & .. & . & . & . & $12 \cdot 8$ & $4 \cdot 94$ & $33 \cdot 6$ & $5 \cdot 04$ \\
\hline & & & . & .. & . & .. & . & . & . & . & $12 \cdot 4$ & $25 \cdot 5$ & $42 \cdot 8$ & $4 \cdot 10$ \\
\hline
\end{tabular}


decrease in blood glucose was observed. Insulin levels were determined during this leucine tolerance curve; there was no increase in plasma insulin, and this was in agreement with the finding of only a slight decrease in blood glucose. That the patient failed to react to a stimulus for insulin production was confirmed when arginine was used as a stimulus for insulin release (Floyd et al., 1966), when there was no significant decrease in blood glucose (Fig.). She was therefore treated with insulin to stimulate glucokinase synthesis. A subsequent liver biopsy (Table III, column 2) revealed a doubling of the glucose phosphorylating enzymes.

The plasma urea levels were low at all times, while normal plasma ammonia levels were observed, the protein intake being $1.5 \mathrm{~g}$. $/ \mathrm{kg}$. at the time of measurement (Table I). Even at a protein intake of $2 \mathrm{~g}$. $/ \mathrm{kg}$., the blood urea remained low (Table I, age 126 days). Similar low levels of urea were found in CSF. This suggested a defect in the urea cycle: as no excretion of citrulline or argininosuccinic acid could be detected, a defect in the urea cycle in the synthesis or utilization of carbamylphosphate was likely. The activity of carbamylphosphate synthetase was found to be low in liver biopsy tissue (Table IV), and later also in postmortem liver tissue $(0 \cdot 28$ and $0 \cdot 24$, normal value 0.67 ). Even more characteristic was the ratio of the ornithine transcarbamylase activity to the carbamylphosphate synthetase activity, which was found to be 43 in the liver biopsy. Russell et al. (1962), and Levin and Russell (1967) report a value of about 10 for this ratio in human liver, which agrees well with our own normal values (Table IV).

The activity of ornithine transcarbamylase was found to be normal, as was that of the other 3 enzymes of the urea cycle (Table IV). The activity of carbamylphosphate synthetase as found here is lower than that found by other workers $(0.6 \mu \mathrm{mole} / \mathrm{min}$. per $\mathrm{g}$. wet weight, as compared with $3.0 \mu \mathrm{mole} / \mathrm{min}$. per g. wet weight; Russell et al., 1962; Räihä and Suihkonen, 1968). The same holds true for ornithine transcarbamylase $(12 \cdot 0$, as compared with $40 \mu \mathrm{mole} / \mathrm{min}$. per g. wet weight). These differences may be methodological. A high ratio of ornithine transcarbamylase activity to carbamylphosphate synthetase activity was observed also in a post-mortem brain biopsy. This may indicate that the enzyme carbamylphosphate synthetase was deficient in brain as well as in liver tissue, though suitable control values were lacking.

\section{Discussion}

Räihä and Suihkonen (1968) have shown that the development of carbamylphosphate synthetase in human liver is completed at birth, so that the low activity of this enzyme in our patient was certainly abnormal. It should be mentioned that pyridine nucleotide biosynthesis is not disturbed by this deficiency, as a cytoplasmic carbamylphosphate synthetase with glutamine as nitrogen donor is responsible for this metabolic route (Jones and Hager, 1966). How far the moderately decreased level of enzyme activity as found in several organs, i.e. liver and brain, relates to the extensive brain damage, remains a question. This low activity of carbamylphosphate synthetase results in reduced activity of the urea cycle, and the low blood urea levels found in our patient. Blood arginine level will also be low (Table II) as the urea cycle is an important part of arginine metabolism, particularly in the synthetic pathway.

Arginine in turn is part of the mechanism for the release of insulin, which in liver induces the enzyme

\section{TABLE IV}

Activities of Urea Cycle Enzymes of Liver ( $\mu$ moles/min. per g. wet weight of tissue)

\begin{tabular}{|c|c|c|c|c|c|c|c|c|c|c|}
\hline & & & & & & & & $\begin{array}{l}\text { Liver } \\
\text { Biopsy }\end{array}$ & $\begin{array}{c}\text { Liver } \\
\text { Post mortem }\end{array}$ & $\begin{array}{c}\text { Brain } \\
\text { Post mortem }\end{array}$ \\
\hline Carbamylphosphate synthetase & . & . & . & . & . & . & . & $\begin{array}{c}0.28 \\
(0.67)\end{array}$ & $\begin{array}{c}0 \cdot 24 \\
(0 \cdot 60)\end{array}$ & $\begin{array}{l}0.025 \\
(0.40)\end{array}$ \\
\hline Ornithine transcarbamylase $\ldots$ & . & . & . & $\cdots$ & . & $\cdots$ & $\cdots$ & $\begin{array}{l}12 \cdot 0 \\
(9 \cdot 23)\end{array}$ & $\begin{array}{c}6 \cdot 71 \\
(5 \cdot 45)\end{array}$ & $\begin{array}{c}0.66 \\
(3 \cdot 45)\end{array}$ \\
\hline Argininosuccinate synthetase & . & . . & . & . & . & . & . & - & $1 \cdot 14$ & $0 \cdot 30$ \\
\hline Argininosuccinate cleavage enzyme & . & $\cdots$ & $\cdots$ & $\cdots$ & . & $\cdots$ & $\cdots$ & $(\overline{3 \cdot 68)}$ & $4 \cdot 62$ & $0 \cdot 38$ \\
\hline $\begin{array}{lll}\cdots & \cdots & \cdots\end{array}$ & $\cdots$ & . & . & . & . & $\cdots$ & .. & (244) & 411 & $12 \cdot 6$ \\
\hline \multicolumn{6}{|c|}{ Ratio ornithine transcarbamylase/carbamylphosphate synthetase } & . & . & $\begin{array}{l}43 \\
(13 \cdot 7)\end{array}$ & $\begin{array}{l}28 \\
(9 \cdot 1)\end{array}$ & $\begin{array}{l}26 \cdot 5 \\
(8 \cdot 6)\end{array}$ \\
\hline
\end{tabular}

* Figures in parenthesis are for normal control liver tissue, obtained surgically from traffic accident case. 
glucokinase (Sharma, Manjeskwan, and Weinhouse, 1963; Sols, Sillero, and Salas, 1965). A moderately high blood glucose level and low blood pyruvate and lactate levels are suggestive of a low rate of glycolysis. In the first liver biopsy a low glucokinase activity was indeed found (Table III). In the second biopsy, done after insulin administration, the glucokinase activity had increased.

It was observed that no additional insulin was secreted after stimulation by leucine (Fig.). (A normal response should increase the plasma insulin level by about $25 \mu \mathrm{U} / \mathrm{ml}$. (Floyd et al., 1966).) This suggested that the insulin secreting mechanism failed to respond to amino acid activation. Insulin was therefore administered, and after this course of insulin treatment was terminated the system reacted normally, as can be seen from the postmortem liver enzyme determination (Table III, column 3). This suggests that a decreased activity of the urea cycle, due to a specific enzyme deficiency, may lead to disturbances in carbohydrate metabolism.

Though the patient initially improved on a low protein diet and blood ammonia levels were never excessively high, the diet failed to prevent extensive brain damage leading to death. The high ratio of ornithine transcarbamylase to carbamylphosphate synthetase activities observed in the brain (Table IV) suggests that the enzyme was missing not only in the liver, where the bulk of urea production takes place, but also in the brain. The role of the urea cycle in the brain has not yet been studied extensively (Kemp and Woodbury, 1965). Further animal experiments will be needed to investigate whether an impaired brain urea cycle can lead to extensive brain damage as observed in our cases.

Despite the decreased carbamylphosphate synthetase activity, the blood ammonia level was normal. This is in contrast to the patients described by Russell et al. (1962) and by Levin and Russell (1967) who had a reduced carbamylphosphate synthetase activity, together with a much more reduced activity of ornithine transcarbamylase. The normal blood ammonia level may have been the result of the low protein intake which was probably responsible for prolonging our patient's life, for her untreated brother and sister lived only 4 weeks.

The familial pattern incidence of our cases is in keeping with carbamylphosphate synthetase deficiency being inherited as a recessive autosomal.

\section{Summary}

A case is described of an infant with a deficiency of carbamylphosphate synthetase in liver and brain. The child died at the age of $7 \frac{1}{2}$ months. Post- mortem examination showed extensive brain damage, particularly in the brain-stem and basal nuclei. Low activity of the urea cycle, due to carbamylphosphate synthetase deficiency, was shown to affect carbohydrate metabolism via decreased insulin secretion and inhibited glucokinase induction.

The parents were unrelated. Of their four other children, two were normal, and two had died at the age of 4 weeks with identical symptoms. The family history suggests that carbamylphosphate synthetase deficiency is an inborn error of metabolism with a recessive inheritance.

Our thanks are due to Dr. E. Ebels, Department of Pathology, University of Groningen, for the necropsies, to Dr. J. Gips, Department of Internal Medicine, University of Groningen, for the ammonia determinations, and to the Department of Surgery, University of Groningen, for specimens of normal liver tissue.

\section{REFERENCES}

Allen, J. D., Cusworth, D. C., Dent, D. E., and Wilson, V. K. (1958). A disease, probably hereditary, characterized by severe mental deficiency and a constant gross abnormality of aminoacid metabolism. Lancet, 1, 182.

Bergmeyer, H. U. (1968). Methods of Enzymatic Analysis, 2nd ed. Academic Press, New York.

Brown, G. W., Jr., and Cohen, P. P. (1959). Comparative biochemistry of urea synthesis. I. Methods for the quantitative assay of urea cycle enzymes in liver. $\mathcal{F}$. biol. Chem., 234, 1769.

Dancis, J., Hutzler, J., and Levitz, M. (1960). Metabolism of the white blood cells in maple-syrup-urine disease. Biochim. biophys. Acta (Amst.), 43, 342.

- , - and - (1963). The diagnosis of maple syrup urine disease (branched-chain ketoaciduria) by the in vitro study of the peripheral leukocyte. Pediatrics, 32, 234.

Estabrook, R. W., and Maitra, P. K. (1962). A fluorimetric method for the quantitative microanalysis of adenine and pyridine nucleotides. Analyt. Biochem., 3, 369.

Floyd, J. C., Jr., Falans, S. S., Conn, J. W., Knopf, R. F., and Rull, J. (1966). Stimulation of insulin secretion by amino acids. f. clin. Invest., 45, 1487.

Freeman, J. M., Nicholson, J. F., Masland, W. S., Rowland, L. P., and Carter, S. (1964). Ammonia intoxication, due to a congenital defect in urea synthesis (abstr.). F. Pediat., 65, 1039.

Gips, H. G. (1968). Diagnostic ammonia tests. Thesis, University of Groningen.

Hohorst, H. J. (1965). L(+)-Lactate, determination with lactic dehydrogenase and DPN. In Methods of Enzymatic Analysis, 2nd ed., p. 266. Ed. by H. U. Bergmeyer. Academic Press, New York.

Jones, M. E., and Hager, S. E. (1966). Source of carbamylphosphate for pyrimidine synthesis in mouse Ehrlich ascites cells and rat liver. Science, 154, 422.

Kemp, J. W., and Woodbury, D. M. (1965). Synthesis of ureacycle intermediates from citrulline in brain. Biochim. biophys. Acta (Amst.), 111, 23.

Levin, B., and Russell, A. (1967). Treatment of hyperammonemia. Amer. F. Dis. Child., 113, 142.

Moore, S., and Stein, W. H. (1954). A modified ninhydrin reagent for the photometric determination of amino acids and related compounds. F. biol. Chem., 211, 907.

McMurray, W. C., Mohyuddin, F., Rossiter, R. J., Rathbun, J. C., Valentine, G. H., Koegler, S. J., and Zarfas, D. E. (1962). Citrullinuria, a new aminoaciduria associated with mental retardation. Lancet, $1,138$.

Räihä, N. C. R., and Suihkonen, J. (1968). Development of ureasynthesizing enzymes in human liver. Acta paediat. scand., 57, 121. 
Russell, A., Levin, B., Oberholzer, V. G., and Sinclair, L. (1962). Hyperammonaemia, a new instance of an inborn enzymatic defect of the biosynthesis of urea. Lancet, 2, 699.

Sharma, C., Manjeskwan, R., and Weinhouse, S. (1963). Effects of diet and insulin on glucose-adenosine triphosphate phosphotransferases of rat liver. $\mathcal{F}$. biol. Chem., 238, 3840.

Sols, A., Sillero, A., and Salas, J. (1965). Insulin-dependent synthesis of glucokinase. f. cell comp. Physiol., 66, Suppl. 1, 23.

Sporn, M. B., Dingman, W., Defalco, A., and Davies, R. K. (1959). Formation of urea from arginine in the brain of the living rat. Nature (Lond.), 183, 1520.

Stein, W. H., and Moore, S. (1954). The free amino acids of human blood plasma. f. biol. Chem., 211, 915.

Walker, D. G., Khan, H. H., and Eaton, S. W. (1966). Enzymes catalyzing the phosphorylation of hexoses in neonatal animals. Biol. Neonat., 9, 224.

\section{Addendum}

Since submission of this paper, 4 other cases of hyperammonaemia due to liver ornithine transcarbamylase deficiency have been described (Hopkins et al.,
1969; Levin et al., 1969a, and Levin et al., 1969b). Striking in these reports are the varying clinical manifestations of the enzyme defect, explained by Levin et al. (1969b) as perhaps the result of different mutations of the gene for ornithine transcarbamylase.

\section{REFERENCES}

Hopkins, I. J., Connelly, J. F., Dawson, A. G., Hird, F. J. R., and Maddison, T. G. (1969). Hyperammonaemia due to ornithine transcarbamylase deficiency. Arch. Dis. Childh., 44, 143.

Levin, B., Abraham, J. M., Oberholzer, V. G., and Burgess, E. A. (1969a). Hyperammonaemia: a deficiency of liver ornithine transcarbamylase: occurrence in mother and child. ibid., 44, 152.

Dobbs, R. H., Burgess, E. A., and Palmer, T. (1969b). Hyperammonaemia: a variant type of deficiency of liver ornithine transcarbamylase. ibid., 44, 162.

Correspondence to Dr. F. A. Hommes, Department of Paediatrics, State University, 59 Oostersingel, Groningen, The Netherlands. 